Article

\title{
Food Sustainability as a Strategic Value Driver in the Hotel Industry
}

\author{
Claudia Cozzio ${ }^{1, *}$, Ludovico Bullini Orlandi ${ }^{2}$ and Alessandro Zardini ${ }^{2}$ (D) \\ 1 Department of Economics and Management, University of Padua, Via del Santo 33, 35123 Padua PD, Italy \\ 2 Department of Business Administration, University of Verona, Via Cantarane 24, 37129 Verona VR, Italy; \\ ludovico.bulliniorlandi@univr.it (L.B.O.); alessandro.zardini@univr.it (A.Z.) \\ * Correspondence: claudia.cozzio@phd.unipd.it
}

Received: 8 September 2018; Accepted: 22 September 2018; Published: 25 September 2018

\begin{abstract}
This paper aims at exploring the impact of green food on consumers' purchase attitudes toward a hotel stay and on consumers' behavioral intentions (i.e., intention to visit the hotel, intention to offer positive recommendations to others and willingness to pay a premium price), focusing on an Italian perspective where the food is a worldwide famous cultural element. This research employed a survey sent out by email to a database of contacts provided by an Italian company that operates in tourism. Data collection was completed in four weeks and the initial dataset counted 3586 of target respondents. A total of 302 surveys were completed and the data were analyzed through structural equation modeling (SEM). Firstly, an exploratory factor analysis (EFA) was performed, followed by a confirmatory factor analysis (CFA) that leads to the estimation of the structural model. The results show that personal beliefs toward green food are positively associated with respondents' purchase attitudes toward green food. Moreover, stronger purchase attitudes toward green food lead to more favorable purchase attitudes toward hotels that offer green food, further substantiating the investigation about whether or not consumers' attitudes employ similar concerns on sustainability for their daily purchases as well as for vacation products and services. In turn, the latter purchase attitudes are positively associated with individual behavioral intentions toward hotels that offer green food.
\end{abstract}

Keywords: sustainable food; green food; sustainability in hotels; consumer beliefs; purchase attitudes; behavioral intentions; structural equation modelling

\section{Introduction}

The supply-side of the tourism industry is trying to adopt sustainable practices [1,2] and, increasingly, going green emerged as a valuable competitive strategy in the hospitality industry [3-5]. As a result, hotel managers need to acquire a greater understanding of current and potential customers' desires and intentions for green consumption [3].

Despite some research efforts that have been focused in examining different sustainable practices in hospitality such as recycling programs, energy efficiency, water conservation, and waste management [6-9], the topic of food sustainability remains unexplored in this context, although the phenomenon is highly relevant, considering the experiential nature of the services and the products offered in the industry [10].

This study aims at addressing this omission. In fact, food can play an essential role in offering green services to customers [11]. More specifically, this paper aims at exploring the impact of green food on consumers' purchase attitudes toward a hotel stay and on consumers' behavioral intentions (i.e., intention to visit the hotel, intention to offer positive recommendations to others and willingness 
to pay a premium price), putting a step further in the investigation about whether or not customers' concerns on sustainability are similar for their daily purchases as well as for their hotel stays.

In addition, the paper provides an all-embracing definition of food sustainability, addressing different dimensions of greenness. In fact, according to some scholars [11,12] it is safe to assume that the concept of green food embeds three main elements such as organic farming, locally grown food, and environmental sustainability. Thus, in addition to locally grown food seen to be produced and consumed within a particular geographical area, reducing the pollution associated with transportation [13], the concepts of organic farming and environmental sustainability emerge as fundamental. In particular, organic farming, as described by $\mathrm{Hu}$ et al. [14], prohibits the use of toxic synthetic pesticides and fertilizers, and the environmentally sustainable food supports the long-term maintenance of ecosystems and agriculture for the future generations [14]. In particular, the consumption of food with low environmental impacts is protective and respectful of biodiversity, culturally acceptable, economically fair because it optimizes natural and human resources [15]. In addition, it refers to animal welfare [16], the empowerment of the local culture and the avoidance of any forms of cultural destruction [17].

Basing on the aforementioned concepts, this research aims at investigating an all-embracing dimension of food sustainability considering three main components derived from the literature (i.e., organic farming, locally grown food, and environmental sustainability). The originality of the research lies in exploring the topic of food sustainability in the hotel scenario that is often defined by scholars in the field as an underexplored perspective [18].

In the following sections, the theoretical background of this study and the research hypotheses are presented. Then, this paper develops an empirical survey that tests the hypothesis through structural equation modeling (SEM). The conclusion and the managerial implications of the results are hereafter developed.

\section{Literature Review and Research Hypothesis}

\subsection{Consumers' Beliefs Toward Green Food}

Many scholars argued that beliefs about a concept have a considerable and direct impact on the individual's attitude toward that concept $[19,20]$. In particular, beliefs are considered to be cognitively derived structures, while attitudes emerged to be evaluative in nature [19]. In that perspective, beliefs are key components in the creation of attitudes since attitudes toward an object flow logically and automatically from an individual's beliefs concerning the aforementioned object [20].

In the hospitality literature, when consumers believe that green consumption decisions will benefit themselves as well as the external environment, they are more in favor of behaving in an environmentally responsible way. In particular, Huang et al. [21] showed that environmental protection consciousness positively affects environmentally friendly behavior of hotel guests.

Therefore, environmental concerns are positively related to consumers' intentions to purchase green products. For instance, Laroche et al. [22] found that environmentally conscious customers who consider ecological issues have a positive attitude toward green behaviors. In addition, in the hospitality industry, Manaktola and Jauhari [4] found that customers that have a great awareness of problems regarding the environment prefer to make eco-friendly purchases.

This research supports the notion of the positive relation between beliefs and purchase attitudes, and it postulates the following hypothesis:

Hypothesis 1 (H1). Consumers' beliefs about green food attributes have a positive impact on general purchase attitudes toward green food.

This paper focuses on an all-embracing concept of green food that considers different dimensions of greenness as derived from the literature [11,12]. Accordingly, it is safe to assume that the concept of green food includes three main components such as organic farming, locally grown food, and 
environmental sustainability. Organic farming refers to agriculture products produced without using pesticides, antibiotics, and genetic modifications [14], local food is seen as produced and consumed within a particular geographical area and environmentally sustainable food is showed as protective and respectful of biodiversity and ecosystems [15]. In addition, the latter dimension includes also animal welfare [16], the empowerment of the local culture and the avoidance of any forms of cultural destruction [17].

\subsection{Consumers' Purchase Attitudes Toward Green Food in the Hotel Industry}

This research aims at investigating whether or not consumers' concerns on sustainability are similar for their daily purchases as well as for their vacation products and services (i.e., hotel stay).

In that context, although it seems rational and logical to suppose that individuals who adopt environmentally friendly behaviors at home will also show environmental awareness in a hotel setting, few studies investigate this empirically [23].

Moreover, while environmentally friendly behaviors in household settings have been broadly investigated, research in hospitality settings is scant [24]. For instance, Clark and Finley [25] found that the degree to which people show awareness of problems concerning the climate change and future water shortages displayed positive and significant correlations with the intention to implement specific water conservation practices at home. Additionally, Gregory and Di Leo [26] suggested that environmental awareness, personal involvement, habits and situational factors (e.g., income) emerged as key drivers for implementing water consumption behaviors in the household settings.

Prior research revealed that environmentally friendly behaviors are more persistent in a household setting while such behaviors in a hotel setting are strongly related to external aspects such as personal comfort, convenience, and cost [24]. In particular, given an increasing awareness of ecological problems, consumers engage in environmentally friendly behaviors in their everyday purchases [25,27]. As environmental awareness increases, consumers with a high degree of consciousness on environmental problems make effort to solve them and they tend to prefer to book an environmentally friendly property instead of a non-green property $[3,4,28,29]$.

For example, many guests prefer to stay in an environmentally friendly property not only for a matter of intrinsic quality characteristics (e.g., allergen-free features), but also for the personal emotions experienced in an environmentally friendly property (e.g., preserving the long-term maintenance of the environment for the future generations) [28]. In other words, such emotional and intangible benefits might drive consumer preferences in the hospitality industry. Additionally, Pereira et al. [30] emphasized that individuals who recognized the importance of sustainable issues in daily purchases are in favor of acknowledging the relevance of purchasing sustainable product also in the hospitality context. Moreover, the authors stated that the concept of sustainability emerged as essential in relation to vacation products and services.

Therefore, this paper expects that general purchase attitudes toward green food will significantly affect purchase attitudes toward a hotel that offers green food. Hence the following hypothesis is proposed:

Hypothesis 2 (H2). General purchase attitudes toward green food positively impact purchase attitudes toward a hotel that offers green food.

\subsection{Consumers' Behavioral Intentions Toward Green Food in Hotel Industry}

The link between attitudes and behavioral intentions has been broadly investigated and it continues to be studied in the consumer behavior literature. The theory of planned behavior $[29,31]$ postulates that individual's behavioral intentions derived from personal attitudes toward the behavior. Accordingly, for the theory of planned behavior, attitudes are antecedents to behavioral intentions [29,31], while beliefs represent the immediate precursor of attitudes [32,33]. 
Basing on Ajzen's [33] theory of planned behavior, some scholars have investigated attitudes as key drivers of consumers' behavioral intentions toward green hotels and restaurants (e.g., [34-38]).

According to Han et al., [3,28], within the hospitality literature, behavioral intentions were represented by three elements: intentions to visit the hotel, intentions to offer positive recommendations to others and willingness to pay a premium price.

In particular, Lee et al. [38] showed that green hotel guests were willing to spread positive recommendations and revisit the green hotel, whereas they were scarcely motivated to pay a premium price. In fact, studies on consumers' willingness to pay for environmental sustainability produced mixed results in the hospitality industry. In particular, some consumers appear unwilling to pay a premium price for the offering of green services in hotels $[4,39,40]$, while others are willing to do so [41-43].

Despite the conflicting findings, this research supports the perspective of the positive relation between purchase attitudes and behavioral intentions, proposing the following hypothesis:

Hypothesis 3a (H3a). Purchase attitudes toward a hotel that offers green food positively impact Willingness to Pay (WTP) for a hotel that offers green food.

Concerning the other behavioral intentions, the intention to visit a green hotel is a behavior that contains elements of personal morality and social responsibility [35], while word of mouth represents a powerful and valuable tool in transferring information within the hospitality industry [44]. In that context, prior researches suggest that customers who are environmentally friendly have greater intentions to visit a green hotel and to spread word-of-mouth about a green hotel and they actually do so $[3,28,29]$. Therefore, this study postulates the following:

Hypothesis $3 \mathbf{b}(\mathbf{H} 3 \mathbf{b})$. Purchase attitudes toward a hotel that offers green food positively impact intention to visit (ITV) a hotel that offers green food.

Hypothesis 3c (H3c). Purchase attitudes toward a hotel that offers green food positively impact word of mouth (WOM) about a hotel that offers green food.

In conclusion, this paper adopts the aforementioned theoretical foundation from which the following conceptual model is derived (see Figure 1):

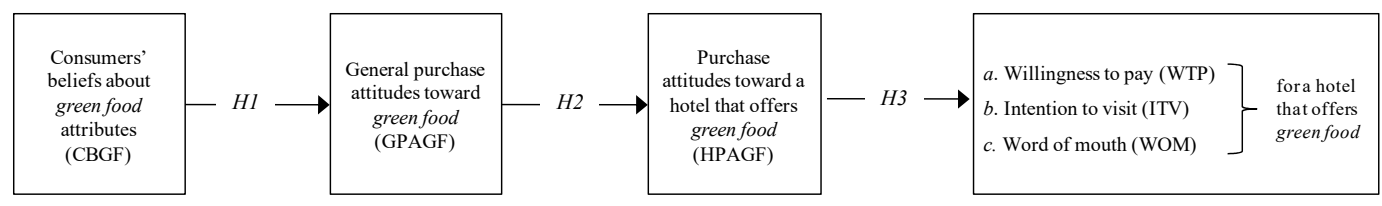

Figure 1. The conceptual model.

Based on the aforementioned theoretical framework, this study aims at investigating the impact of consumers' beliefs about green food (CBGF) on consumers' purchase attitudes toward daily green food purchases (GPAGF), which are likely to affect the purchase attitudes toward a hotel that offer green food (HPAGF). In turn, the conceptual model hypothesizes that the latter purchase attitudes influence individual behavioral intentions toward hotels that offer green food (i.e., willingness to pay a premium price [WTP], intention to visit [ITV], intention to offer positive recommendations [WOM]).

\section{Methodology}

\subsection{The Questionnaire}

The questionnaire consists of five sections and the measures derived from a wide review of the literature. 
Table 1. Constructs, items, and sources

\begin{tabular}{|c|c|c|c|c|}
\hline Construct & Items \# & Key Areas & Scale Items (Item Loading) & Source \\
\hline $\begin{array}{l}\text { Consumer beliefs about } \\
\text { green food attributes (CBGF) }\end{array}$ & $\begin{array}{c}\text { FBE } 1 \\
\text { FBE } 2 \\
\text { FBE } 3 \\
\text { FBH 1 } \\
\text { FBH } 2 \\
\text { FBH } 3 \\
\text { FBS } \\
\text { FBP }\end{array}$ & $\begin{array}{c}\text { Environment } \\
\text { Environment } \\
\text { Environment } \\
\text { Health } \\
\text { Health } \\
\text { Health } \\
\text { Sensory } \\
\text { Price }\end{array}$ & $\begin{array}{l}\text { Consumers perceptions about green food attributes: } \\
\text { It is related to environmental protection }(0.73) \\
\text { It not breaks the balance of the nature }(0.80) \\
\text { It is produced with acceptance of ethical standard (0.72) } \\
\text { It supports a healthy diet }(0.74) \\
\text { It has no harmful ingredients }(0.84) \\
\text { It has high safety standards }(0.77) \\
\text { It has a pleasant taste }(0.61) \\
\text { It has not a good value-for-money }(0.41)\end{array}$ & [45-47] \\
\hline $\begin{array}{l}\text { General purchase attitudes } \\
\text { toward green food (GPAGF) }\end{array}$ & $\begin{array}{l}\text { GPAO } 1 \\
\text { GPAO } 2 \\
\text { GPAI } 1 \\
\text { GPAI } 2 \\
\text { GPAL }\end{array}$ & $\begin{array}{l}\text { Price } \\
\text { Health } \\
\text { Information } \\
\text { Information } \\
\text { Ethical concerns }\end{array}$ & $\begin{array}{l}\text { I do not mind paying higher prices for organic food }(0.58) \\
\text { It is important for me to buy natural products }(0.81) \\
\text { To me product information is of high importance. I need to know what the product contains }(0.89) \\
\text { I compare labels to select the food that I consider more beneficial to health }(0.74) \\
\text { I prefer to buy food produced in my country }(0.44)\end{array}$ & {$[48,49]$} \\
\hline $\begin{array}{l}\text { Purchase attitudes toward a } \\
\text { hotel that offers green food } \\
\text { (HPAGF) }\end{array}$ & $\begin{array}{l}\text { HPAB } 1 \\
\text { HPAB } 2 \\
\text { HPAH } 1 \\
\text { HPAH } 2 \\
\text { HPAH } 3 \\
\text { HPAE } 1 \\
\text { HPAE } 2 \\
\text { HPAE } 4 \\
\text { HPAL } \\
\text { HPAP }\end{array}$ & $\begin{array}{l}\text { Brand } \\
\text { Brand } \\
\text { Health } \\
\text { Health } \\
\text { Health } \\
\text { Environment } \\
\text { Environment } \\
\text { Environment } \\
\text { Local } \\
\text { Price }\end{array}$ & $\begin{array}{l}\text { When I consider buying a vacation in hotel, I consider important that: } \\
\text { The food has brand as a trustful element for certifying food production methods }(0.90) \\
\text { The food has brand as a trustful element for certifying environmentally friendly food }(0.89) \\
\text { The food contains natural ingredients }(0.90) \\
\text { The food contains no artificial ingredients }(0.77) \\
\text { The food is certified free of chemicals and hormone residues }(0.89) \\
\text { The food is produced in a way that preserves its natural goodness }(0.86) \\
\text { The food is produced in an environmentally friendly way ( } 0.85) \\
\text { The food is produced in a way that has not shaken the balance of nature }(0.79) \\
\text { The food is grown locally ( } 0.46) \\
\text { The food served in the hotel has a good value-for-money }(0.41)\end{array}$ & [50-52] \\
\hline Willingness to pay (WTP) & $\begin{array}{l}\text { WTP1 } \\
\text { WTP2 } \\
\text { WTP3 }\end{array}$ & & $\begin{array}{l}\text { I am willing to spend extra to stay in a hotel that offers green food }(0.98) \\
\text { It is acceptable to pay more for a hotel that offers green food }(0.89) \\
\text { I am willing to pay more for a hotel that offers green food }(0.91)\end{array}$ & \\
\hline Intention to visit (ITV) & $\begin{array}{l}\text { ITV1 } \\
\text { ITV2 } \\
\text { ITV3 }\end{array}$ & & $\begin{array}{l}\text { I am willing to stay at a hotel that offers green food when I'm travelling }(0.62) \\
\text { I plan to stay at a hotel that offers green food when I'm travelling }(0.82) \\
\text { I will make an effort to stay at a hotel that offers green food when I'm travelling }(0.82)\end{array}$ & {$[28,29,34,38,52]$} \\
\hline Word of mouth (WOM) & $\begin{array}{l}\text { WOM1 } \\
\text { WOM2 } \\
\text { WOM3 }\end{array}$ & & $\begin{array}{l}\text { If someone is looking for a hotel, I will suggest to him/her to stay in a hotel that offers green food ( } 0.75) \\
\text { I will positively talk about an hotel that serves green food }(0.40) \\
\text { I encourage my friends and relative to stay in a hotel that offers green food }(0.72)\end{array}$ & \\
\hline
\end{tabular}


The first section refers to personal beliefs about green food attributes. Survey participants were asked to indicate for a variety of green food attributes their level of agreement or disagreement according to a seven-point Likert scale. Measures for consumers' beliefs toward green food attributes were adopted from prior researches focused on green products $[45,46]$. The measurement scale comprised eight items taking the form: "How strongly do you agree or disagree with the following statements?". Following the studies mentioned above, four key attributes' areas emerged related to environment, health, sensory, and price (Table 1).

The second section aims at investigating the general purchase attitudes toward green food in everyday lives. Respondents were asked to evaluate their level of agreement on each item on a seven-point Likert scale. The five statements of this questionnaire's section were derived from a food choice questionnaire (FCQ) as described by Steptoe et al. [48] and a food-related lifestyle questionnaire developed by Grunert et al. [49]. In particular, the FCQ consisted of items referring to aspects such as health, price and ethical concerns, while the items derived from Grunert et al. [49] referred to the importance of product information (Table 1).

The third section contains questions to evaluate purchase attitudes toward a hotel that offers green food. The measurement scale comprised ten items taking the form: "When I consider buying a vacation in hotel, I consider important that", ranging from strongly disagree (1) to strongly agree (7). In particular, eight items were adapted from Lockie's et al. [50] food consumption questionnaire pointing out different key attributes' areas related to health, environmental protection, locally grown or not, and price (Table 1). In addition, two items were adapted from Krystallis et al. [51] range of trust items that comprise trust in a quality logo and trust food certification bodies. The items were slightly modified for the context of trust a food brand in a hotel (Table 1).

The fourth section explores the behavioral intentions: the key dimensions of behavioral intentions include revisit intention, word-of-mouth intention and willingness to pay [53]. The measurement items were generated in coherence with previous researches $[28,29,34,38]$. In particular, the items were adapted for the context of a hotel that offers green food and all the constructs were measured with multiple items through a seven-point Likert scale. Multi-item scales were used to assess the constructs (Table 1).

The last section includes questions about demographic information such as gender, age, level of education, household income and frequency of a hotel stay in the past 12 months [28].

\subsection{Data Collection and Sample Characteristics}

This research employed a survey that was developed and refined in collaboration with two experts of the topic from academia and two from tourism business field. A pretest on a subsample of 40 respondents was conducted in order to verify the efficacy of the constructs.

Therefore, an online survey was conducted, and a questionnaire was purposefully designed through Google Form. The utilization of an online survey is becoming acceptable in the academic research because it is easier to obtain more candid response [28,29].

The opening instructions of the survey defined clearly the concept of green food as understood to be organic, local and sustainable [11,12]. In particular the survey opens as follows: The following questionnaire aims at investigating the concept of green food within the hotel industry. Based on the definition adopted from the literature [11,12], the term green food refers equally to organic certified food (i.e., food produced without the use of chemicals), locally grown food (i.e., food produced and consumed within a particular geographical area), environmentally sustainable food (i.e., food protective and respectful of biodiversity and ecosystems). The survey was sent out by email to a database of contacts provided by an Italian domestic hotel chain that manages three seaside resorts located in the south of Italy. The target consumers of the three resorts are homogeneous and the services offered are similar and standardized among the three resorts. The database comprised potential clients who have asked for a quotation through the company website (from October 2016 to May 2017). The domestic hotel chain was chosen as a set of analysis due to its scarce sensibility to sustainable 
issues in tourism. In that way, the domestic hotel chain represents a neutral setting that guarantees candid response based on respondents' personal opinions. Additionally, the authors chose to focus specifically on the potential customers in order to rely on objective point of views not influenced by the stay at the hotels.

Data collection took place from 10 July 2017 to 6 August 2017, with one reminder email sent on 30 July 2017. The collection of questionnaires complied with Italian privacy laws and aggregate use of the data was assured to the respondents. Data collection was completed in four weeks and the initial dataset counted 3.586 of target respondents. A total of 302 surveys were completed and usable for an $8.42 \%$ of response rate.

Table 2 shows the descriptive statistics of the sample.

Table 2. Sample characteristics.

\begin{tabular}{|c|c|c|}
\hline Demographic & Count & $(\%)$ \\
\hline \multicolumn{3}{|l|}{ Gender } \\
\hline Female & 148 & 49.0 \\
\hline Male & 154 & 51.0 \\
\hline \multicolumn{3}{|l|}{ Age } \\
\hline Born between 1946 and 1964 (Baby Boomers) & 82 & 27.2 \\
\hline Born between 1965 and $1980($ Gen X) & 165 & 54.6 \\
\hline Born between 1981 and 2000 (Gen Y) & 55 & 18.2 \\
\hline \multicolumn{3}{|l|}{ Study level } \\
\hline Primary School & 17 & 5.6 \\
\hline High School & 145 & 48.0 \\
\hline University Degree & 114 & 37.7 \\
\hline Post-graduate professional degree & 21 & 7.0 \\
\hline Ph.D. & 5 & 1.7 \\
\hline \multicolumn{3}{|l|}{ Income } \\
\hline$<15,000$ & 42 & 13.9 \\
\hline between 15,001 and 28,000 & 131 & 43.4 \\
\hline between 28.001 and 55,000 & 106 & 35.1 \\
\hline between 55,001 and 75,000 & 21 & 7.0 \\
\hline$>75,001$ & 2 & 0.7 \\
\hline \multicolumn{3}{|l|}{$\begin{array}{c}\text { Number of times stayed in hotels in the past } 12 \\
\text { months }\end{array}$} \\
\hline None & 6 & 2.0 \\
\hline Once & 75 & 24.8 \\
\hline between 2 and 4 & 167 & 55.3 \\
\hline more than 4 & 54 & 17.9 \\
\hline
\end{tabular}

\section{Data Analysis and Results}

\subsection{Preliminary Data Analysis}

In order to verify the set of theoretical hypotheses, this study employed the correlation-based structural equation modelling (CB-SEM). This type of method is more suitable for theory testing, especially in case of not too complex models with a sufficiently large number of observations [54].

Before starting the analysis of the CB-SEM, some preliminary data analyses were performed to address the following issues: non-response bias, multicollinearity, common method variance (CMV).

The preliminary data analysis and the exploratory factor analysis (EFA) were performed with SPSS (v. 23). Instead, the confirmatory factor analysis (CFA) and the estimation of the structural model were performed with the R package, lavaan.

This research employed late respondents as a proxy for non respondents to check for nonresponse bias, and the $t$-test to compare the differences between early and late respondents. The findings do not display significant differences, suggesting that nonresponse bias is not an issue in this study. 
The VIF scores were calculated to test the possible multicollinearity: all the variance inflation factors range from 1.29 to 1.81, largely below the suggested threshold of five [55].

During the development of the survey and the data collection, the best practices to control the CMV were followed such as assuring anonymity to the respondents and avoiding items' social desirability, demand characteristics and ambiguity [56]. Once the data were collected, Harman's single-factor test was employed to verify the presence of common method bias [56]. The first single factor in the unrotated factor matrix explained the $37.5 \%$ of the variance, fairly below the suggested $50 \%$ threshold.

\subsection{The Analysis of Reliability, Convergent and Discriminant Validity}

The model was also tested to check the level of reliability, convergent validity, and discriminant validity.

Reliability was assessed reporting the Cronbach's alpha (CA) and the Composite Reliability (CR) scores (Table 3). The findings suggest that they are all above the recommended threshold of 0.7 [57].

Almost all the average variances extracted (AVE) exceed the recommended threshold of 0.5, suggesting convergent validity [58]. In that context, only the CPGF constructs appear slightly below the threshold (0.42).

Anyway, since the squared root of AVE is always greater than each of the other inter-constructs correlations, this evidence suggests the presence of discriminant validity [58].

Table 3. Assessment of constructs' convergent and discriminant validity.

\begin{tabular}{lccccccccccc}
\hline Constructs & M & SD & CR & CA & AVE & $\mathbf{1}$ & $\mathbf{2}$ & $\mathbf{3}$ & $\mathbf{4}$ & $\mathbf{5}$ & $\mathbf{6}$ \\
\hline 1. CBGF & 5.39 & 0.94 & 0.85 & 0.85 & 0.42 & $\mathbf{0 . 6 5}$ & & & & & \\
2. GPAGF & 5.91 & 0.96 & 0.86 & 0.75 & 0.52 & 0.46 & $\mathbf{0 . 7 2}$ & & & & \\
3. HPAGF & 6.01 & 0.98 & 0.93 & 0.94 & 0.81 & 0.39 & 0.63 & $\mathbf{0 . 9 0}$ & & & \\
4. WTP & 4.64 & 1.56 & 0.93 & 0.93 & 0.82 & 0.31 & 0.39 & 0.38 & $\mathbf{0 . 9 1}$ & & \\
5. ITV & 4.66 & 1.44 & 0.87 & 0.86 & 0.69 & 0.43 & 0.56 & 0.48 & 0.73 & $\mathbf{0 . 8 3}$ & \\
6. WOM & 5.44 & 1.26 & 0.86 & 0.85 & 0.68 & 0.49 & 0.59 & 0.52 & 0.69 & 0.80 & $\mathbf{0 . 8 2}$ \\
\hline
\end{tabular}

1. $\mathrm{M}=$ mean; $\mathrm{SD}=$ standard deviation; $\mathrm{CR}=$ Composite reliability; $\mathrm{CA}=$ Cronbach's alpha; $\mathrm{AVE}=$ average variance extracted. 2. Numbers on the diagonal are the square root of AVEs. The other numbers are correlations among constructs.

\subsection{Results of the Measurement Model}

To test the measurement model, an EFA was first performed and, in terms of factor loadings, all the items' loadings are greater than 0.5 , except for two that are greater than 0.4 (Table 1). Anyway, also values greater than 0.4 are considered statistically significant factor loadings [57] due to the relevant sample size of the study.

The measurement model was also validated employing CFA, and the results display an adequate fit index, suggesting good fit between measurement model and data (Table 3). The CFA displays a $\chi^{2}$ of 1170.3 with $480 \mathrm{df}$ and a ratio of $\chi^{2} / \mathrm{df}$ equal to 2.43 , less than 3:1 as suggested in the literature [57]. The other indices CFI $=0.90$, GFI $=0.97$, AGFI $=0.96$ and $\mathrm{RMSEA}=0.069$ respect the recommended threshold for good fit [57].

The resulting model strongly supports the theoretical hypothesis (Table 4).

Table 4. Results of the structural model.

\begin{tabular}{ccccccc}
\hline Hypothesis & Path & Estimate & Standard Error & $\boldsymbol{z}$-Value & $\boldsymbol{p}$-Value & Decision \\
\hline H1 & GPAGF $\leftarrow$ CBGF & 0.54 & 0.07 & 7.95 & 0.000 & Supported \\
H2 & HPAGF $\leftarrow$ GPAGF & 0.74 & 0.07 & 10.59 & 0.000 & Supported \\
H3a & WTP $\leftarrow$ HPAGF & 0.69 & 0.10 & 7.06 & 0.000 & Supported \\
H3b & ITV $\leftarrow$ HPAGF & 0.80 & 0.10 & 8.25 & 0.000 & Supported \\
H3c & WOM $\leftarrow$ HPAGF & 0.88 & 0.09 & 9.57 & 0.000 & Supported \\
\hline
\end{tabular}


The results show that the relationship between consumer beliefs about green food attributes (CPGF) and general purchase attitudes towards green food (GPAGF) - i.e., H1 -is significant due to the presence of a positive coefficient of 0.54 and $p$-value $<0.001$.

The second hypothesis $(\mathrm{H} 2)$ which represents the relation between general purchase attitudes toward green food (GPAGF) and the purchase attitudes toward a hotel that offers green food (HPAGF) is supported given the presence of a coefficient of 0.74 and $p$-value $<0.001$.

Lastly, concerning the three hypotheses about the impact of the purchase attitudes toward a hotel that offers green food (HPAGF) on the consumers' behavioral intentions, the empirical results support all of them, in fact:

- $\quad$ H3a that hypothesizes the positive relation between HPAGF and willingness to pay (WTP) is supported by the presence of a positive coefficient of 0.69 and $p$-value $<0.001$;

- $\quad$ H3b that hypothesizes the relation between HPAGF and intention to visit (ITV) is supported by the presence of a positive coefficient of 0.80 and $p$-value $<0.001$;

- $\mathrm{H} 3 \mathrm{c}$ that hypothesizes the relation between HPAGF and intention to give positive recommendations to others (WOM) is supported by the presence of a positive coefficient of 0.88 and $p$-value $<0.001$.

\section{Discussion and Conclusions}

This study aims at exploring the impact of green food on consumers' purchase attitudes toward a hotel stay and on consumers' behavioral intentions (i.e., intention to visit the hotel, intention to offer positive recommendations to others and willingness to pay a premium), focusing on an Italian perspective. Prior researches showed that the concept of food sustainability in the hospitality industry appears underexplored since more relevance was given to the investigation of other sustainable practices in the field such as recycling programs (i.e., towel reuse) and energy efficiency $[6,7]$.

The results show that personal beliefs toward green food, as immediate precursors to the attitudes [32,33], are positively associated with respondents' purchase attitudes toward green food. Moreover, stronger purchase attitudes toward green food lead to greater purchase attitudes toward hotels that offer green food. Hence, both $\mathrm{H} 1$ and $\mathrm{H} 2$ are supported.

In turn, the latter purchase attitudes are positively associated with individual behavioral intentions toward hotels that offer green food. Hence H3a, H3b, H3c are also supported. These results are in line with the previous research findings $[4,26,29]$ in terms of attitudes as antecedents to behavioral intentions.

Hence, beliefs are found to positively affect purchase attitudes toward green food, which exert a positive influence on purchase attitudes toward a hotel that offers green food which, in turn, contribute to more favorable behavioral intentions.

Moreover, the significant and positive effect between general purchase attitudes toward green food and purchase attitudes toward a hotel that offers green food puts a step further in the investigation about whether or not consumers' considerations on sustainable issues regarding green food are similar for their daily purchases as well as for vacation products and services. Since few studies investigate this empirically [23], the research findings are particularly relevant because they strengthen an unexplored relation and they shed light upon the topic of green food that represents an underexplored perspective in the hospitality context [20]. In addition, the findings are in line with the theoretical concept of selfish altruism proposed by Miller [59]. Miller [59] emphasized this concept by describing how environmentally conscious consumers are more disposed to purchase products that are of benefit to them as well as to the external environment, rather than just to the rest of world. The fact that the $\mathrm{H} 3 \mathrm{a}, \mathrm{H} 3 \mathrm{~b}$, and $\mathrm{H} 3 \mathrm{c}$ are supported with positive and significant coefficients corroborates and validates the concept of selfish altruism. In other words, in the case of green food the personal (healthiness/wellbeing) and external (environmental) benefits appear well balanced and mixed together. In fact, the term green food embeds the concept of organic farming, locally grown food, and environmental sustainability - features that in turn contribute to the environmental protection and 
offer nutritional and health advantages. Moreover, the originality of the paper lies in adopting the aforementioned all-embracing concept of food sustainability composed by three different dimensions of greenness derived from the literature [11,12] such as organic farming, locally grown food, and environmental sustainability.

Adopting a pragmatic lens, the current study could be considered as a precursor of an emerging field in tourism called agritourism and it sheds light upon the readiness of the market toward this new trend. In particular, agritourism offers farmers the possibility of diversifying and becoming hoteliers through on-farm touristic activities. This helps to maintain the viability of active farms and rural communities and to promote agricultural resources, traditions and culture.

Additionally, the study provides practitioners with a detailed understanding of consumer attitudes and behavioral intentions toward green food in hotel industry, revealing that it is important for hotels to implement promotional incentives in order to make their green practices visible to consumers. In particular, they should effectively communicate the hotel's comprehensive green food philosophy in order to ensure that guests are well-informed. In that context, redesigning hotel menus by presenting information on the nutritional qualities of food together with the indication of the food provenance could be an important issue to address the need of health and personal well-being consciousness and to foster the progress of hospitality practitioners towards the goal of environmental sustainability.

While the current research has shed some lights on several significant issues, there are some limitations that reveal the opportunity for future studies. First, future studies should include other cultures for further comparisons since the study has a marked Italian perspective. Hence, one should be careful with any generalizations to other cultures. Second, it is important to note that the current research tested for behavioral intentions, which do not necessarily lead to actual behaviors (i.e., actually purchase a hotel that offers green food). In particular, for future studies, a valuable attempt would be represented by the investigation of actual tourists' consumption patterns in response to green food promotional campaigns in a real hotel setting. In addition, since from the literature the concept of food sustainability embeds three main components (i.e., organic farming, locally grown food, and environmental sustainability), future research should investigate the influential power of each specific dimension of greenness in promoting food sustainability in the hotel industry.

Author Contributions: Conceptualization, C.C.; methodology, software, validation, formal analysis L.B.O.; investigation, resources, data curation, C.C.; writing-original draft preparation, C.C., L.B.O. and A.Z.; supervision, A.Z.

Funding: This research received no external funding.

Conflicts of Interest: The authors declare no conflicts of interest.

\section{References}

1. Griffin, T.; Delacey, T. Green globe: Sustainability accreditation for tourism. In Sustainable Tourism-A Global Perspective; Harris, R., Griffin, T., Williams, P., Eds.; Elsevier Butterworth-Heinemann: Oxford, UK, 2003; pp. 58-88.

2. Zimmer, M.R.; Stafford, T.F.; Stafford, M.R. Green issues: Dimensions of environmental concern. J. Bus. Res. 1994, 30, 63-74. [CrossRef]

3. Han, H.; Hsu, L.-T.; Lee, J.S. Empirical investigation of the roles of attitudes toward green behaviours, overall image, gender, and age in hotel customers' eco-friendly decision-making process. Int. J. Hosp. Manag. 2009, 28, 519-528. [CrossRef]

4. Manaktola, K.; Jauhari, V. Exploring consumer attitude and behaviour towards green practices in the lodging industry in India. Int. J. Contemp. Hosp. Manag. 2007, 19, 364-377. [CrossRef]

5. Wolfe, K.L.; Shanklin, C.W. Environmental practices and management concerns of conference center administrators. J. Hosp. Tour. Res. 2001, 25, 209-216. [CrossRef]

6. Dimara, E.; Manganari, E.; Skuras, D. Don't change my towels please: Factors influencing participation in towel reuse programs. Tour. Manag. 2017, 59, 425-437. [CrossRef] 
7. Chan, W.W. Environmental measures for hotels' environmental management systems ISO 14001. Int. J. Contemp. Hosp. Manag. 2009, 21, 542-560. [CrossRef]

8. Mensah, I. Environmental Management Practices among Hotels in the Greater Accra Region. Int. J. Hosp. Manag. 2006, 25, 414-431. [CrossRef]

9. Mehta, H.; Riba, A.; Baez, A.; O'Loughlin, P. International Ecolodge Guidelines; The International Ecotourism Society, OMT, WTO, BTO: Burlington, VT, USA, 2002.

10. Williams, A. Tourism and hospitality marketing: Fantasy, feeling and fun. Int. J. Contemp. Hosp. Manag. 2006, 18, 482-495. [CrossRef]

11. Jang, Y.J.; Kim, W.G.; Bonn, M.A. Generation Y consumers' selection attributes and behavioural intentions concerning green restaurants International. J. Hosp. Manag. 2011, 30, 803-811. [CrossRef]

12. LaVecchia, G. Green: The new gold. Restaur. Hosp. 2008, 92, 36-47.

13. Pizam, A. Green hotels: A fad, ploy or fact of life? Int. J. Hosp. Manag. 2009, 28, 1. [CrossRef]

14. Hu, H.; Parsa, H.G.; Self, J. The dynamics of green restaurant patronage. Cornell Hosp. Q. 2010, 51, $344-362$. [CrossRef]

15. Burlingame, B.; Dernini, S. Sustainable diets and biodiversity. Direction and solutions for policy, research and action. In Proceedings of the International Scientific Symposium Biodiversity and Sustainable Diets United Against Hunger, Rome, Italy, 3-5 November 2010; FAO Headquarter: Rome, Italy, 2010.

16. Naspetti, S.; Zanoli, R. Organic Food Quality and Safety Perception throughout Europe. J. Food Prod. Mark. 2009, 15, 249-266. [CrossRef]

17. Nukoo, R. Governance and Sustainable Tourism: What is the Role of Trust, Power and Social Capital? J. Destin. Mark. Manag. 2017, 6, 277-285.

18. Kim, S.; Lee, K.; Fairhurst, A. The review of green research in hospitality, 2000-2014: Current trends and future research directions. Int. J. Contemp. Hosp. Manag. 2017, 29, 226-247. [CrossRef]

19. Fishbein, M.; Raven, B.H. The AB scales: An operational definition of belief and attitude. Hum. Relat. 1962, 15, 35-44. [CrossRef]

20. Ajzen, I. The theory of planned behaviour: Reactions and reflections. Psychol. Health 2011, 26, 1113-1127. [CrossRef] [PubMed]

21. Huang, H.; Lin, T.; Lai, M.; Lin, T. Environmental consciousness and green customer behaviour: An examination of motivation crowding effect. Int. J. Hosp. Manag. 2014, 40, 139-149. [CrossRef]

22. Laroche, M.; Bergeron, J. And Barbaro-Forleo, G. Targeting consumers who are willing to pay more for environmentally friendly products. J. Consum. Mark. 2001, 18, 503-518. [CrossRef]

23. Dolnicar, S.; Leisch, F. An investigation of tourists' patterns of obligation to protect the environment. J. Travel Res. 2008, 46, 381-391. [CrossRef]

24. Miao, L.; Wei, W. Consumers' pro-environmental behaviour and the underlying motivations: A comparison between household and hotel setting. Int. J. Hosp. Manag. 2013, 32, 102-112. [CrossRef]

25. Clark, W.A.; Finley, J.C. Determinants of water conservation intention in Blagoevgrad, Bulgaria. Soc. Nat. Resour. Int. J. 2007, 20, 613-627. [CrossRef]

26. Gregory, D.G.; Di Leo, M. Repeated behaviour and environmental psychology: The role of personal involvement and habit formation in exploring water consumption. J. Appl. Soc. Psycol. 2003, 33, 1261-1296. [CrossRef]

27. Kalafatis, S.P.; Pallard, M.; Markos, R.E. Green marketing and Ajzen's theory of planned behaviour: A cross-market examination. J. Consum. Mark. 1999, 16, 441-460. [CrossRef]

28. Han, H.; Hsu, L.T.-J.; Lee, J.-S.; Sheud, C. Are lodging customers ready to go green? An examination of attitudes, demographics, and eco-friendly intentions. Int. J. Hosp. Manag. 2011, 30, 345-355. [CrossRef]

29. Han, H.; Kim, Y. An investigation of green hotel customers' decision formation: Developing an extended model of the Theory of Planned Behaviour. Int. J. Hosp. Manag. 2010, 29, 659-668. [CrossRef]

30. Pereira, E.M.V.; Mykletun, R.J.; Hippolyte, C. Sustainability, daily practices and vacation purchasing: Are they related? Tour. Rev. 2012, 7, 40-54. [CrossRef]

31. Ajzen, I.; Fishbein, M. Understanding Attitudes and Predicting Social Behaviour; Prentice-Hall: Englewood Cliffs, NJ, USA, 1980.

32. Ajzen, I. The theory of planned behaviour. Organ. Behav. Hum. Decis. Process. 1991, 50, 179-211. [CrossRef]

33. Fishbein, M.; Ajzen, I. Belief, Attitude, Intention and Behaviour: An Introduction to Theory and Research; Addison-Wesley: Reading, MA, USA, 1975. 
34. Line, N.D.; Hanks, L. The effects of environmental and luxury beliefs on intention to patronize green hotels: The moderating effect of destination image. J. Sustain. Tour. 2015, 24, 1-22. [CrossRef]

35. Chen, M.F.; Tung, P.J. Developing an extended theory of planned behaviour model to predict consumers' intention to visit green hotels. Int. J. Hosp. Manag. 2014, 36, 221-230. [CrossRef]

36. Kim, Y.J.; Njite, D.; Hancer, M. Anticipated emotion in consumers' intentions to select eco-friendly restaurants: Augmenting the theory of planned behaviour. Int. J. Hosp. Manag. 2013, 34, 255-262. [CrossRef]

37. Teng, Y.M.; Wu, K.S.; Liu, H.H. Integrating altruism and the theory of planned behaviour to predict patronage intention of a green hotel. J. Hosp. Tour. Resour. 2013, 39, 299-315. [CrossRef]

38. Lee, J.; Hsu, L.; Heesup, H.; Yunhi, K. Understanding how consumers view green hotels: How a hotel's green image can influence behavioural intentions. J. Sustain. Tour. 2010, 18, 901-914. [CrossRef]

39. Choi, G.; Parsa, H.G. Green practices II: Measuring restaurant managers' psychological attributes and their willingness to charge for the green practices. J. Food Serv. Bus. Res. 2007, 9, 41-63. [CrossRef]

40. Carrigan, M.; Attalla, A. The myth of the ethical consumer-do ethics matter in purchase behaviour? J. Consum. Mark. 2001, 18, 560-578. [CrossRef]

41. Tang, C.M.F.; Lam, D. The role of extraversion and agreeableness traits on Gen Y's attitudes and willingness to pay for green hotels. Int. J. Contemp. Hosp. Manag. 2017, 29, 607-623. [CrossRef]

42. Kang, K.H.; Stein, L.; Heo, C.Y.; Lee, S. Consumers' willingness to pay for green initiatives of the hotel industry. Int. J. Hosp. Manag. 2012, 31, 564-572. [CrossRef]

43. Dodds, R.; Graci, S.R.; Holmes, M. Does the tourist care? A comparison of tourists in Koh Phi Phi, Thailand and GiliTrawangan, Indonesia. J. Sustain. Tour. 2010, 18, 207-222. [CrossRef]

44. Kim, W.G.; Han, J.S.; Lee, E. Effects of relationship marketing on repeat purchase and Word of Mouth. J. Hosp. Tour. Res. 2001, 25, 272-288. [CrossRef]

45. Bonn, M.A.; Cronin, J.J., Jr.; Meehee, C. Do Environmental Sustainable Practices of Organic Wine Suppliers Affect Consumers' Behavioural Intentions? The Moderating Role of Trust. Cornell Hosp. Q. 2015, 57, $21-37$. [CrossRef]

46. Żakowska-Biemans, S. Polish consumer food choices and beliefs about organic food. Br. Food J. 2011, 113, 122-137. [CrossRef]

47. Fotopoulos, C.; Krystallis, A. Purchasing motives and profile of the Greek organic consumer: A countrywide survey. Br. Food J. 2002, 104, 730-765. [CrossRef]

48. Steptoe, A.; Pollard, T.; Wardle, J. Development of a measure of the motives underlying the selection of food: The food choice questionnaire. Appetite 1995, 25, 267-284. [CrossRef] [PubMed]

49. Grunert, K.G.; Brunsø, K.; Bisp, S. Food-Related Life Style: Development of a Cross-Culturally Valid Instrument for Market Surveillance; MAPP Working Paper N. 12; The Aarhus School of Business: Aarhus, Denmark, 1993.

50. Lockie, S.; Lyons, K.; Lawrence, G.; Grice, J. Choosing organics: A path analysis of factors underlying the selection of organic food among Australian consumers. Appetite 2004, 43, 135-146. [CrossRef] [PubMed]

51. Krystallis, A.; Chryssohoidis, G. Consumers' willingness to pay for organic food: Factors that affect it and variation per organic product type. Br. Food J. 2005, 107, 320-343. [CrossRef]

52. Rossignoli, C.; Ricciardi, F.; Bonomi, S. Organizing for Commons-Enabling Decision-Making under Conflicting Institutional Logics in Social Entrepreneurship. Group Decis. Negotiat. 2018, 27, 417-443. [CrossRef]

53. Zeithaml, V.A.; Berry, L.L.; Parasuraman, A. The behavioural consequences of service quality. J. Mark. 1996, 60, 31-46. [CrossRef]

54. Hair, J.F.; Hult, G.T.M.; Ringle, C.M.; Sarstedt, M. A Primer on Partial Least Squares Structural Equation Modeling; Sage: Thousand Oaks, CA, USA, 2014.

55. Hair, J.F.; Sarstedt, M.; Ringle, C.M.; Mena, J.A. An assessment of the use of partial least squares structural equation modeling in marketing research. J. Acad. Mark. Sci. 2012, 40, 414-433. [CrossRef]

56. Podsakoff, P.M.; MacKenzie, S.B.; Lee, J.-Y.; Podsakoff, N.P. Common method biases in behavioural research: A critical review of the literature and recommended remedies. J. Appl. Psychol. 2003, 88, 879-890. [CrossRef] [PubMed]

57. Hair, J.F.; Black, W.C.; Babin, B.J.; Anderson, R.E. Multivariate Data Analysis: A Global Perspective; Pearson: Upper Saddle River, NJ, USA, 2010. 
58. Fornell, C.; Larcker, D.F. Evaluating structural equation models with unobservable variables and measurement error. J. Mark. Res. 1981, 18, 39-50. [CrossRef]

59. Miller, G.A. Consumerism in sustainable tourism: A survey of UK consumers. J. Sustain. Tour. 2003, 11, 17-39. [CrossRef]

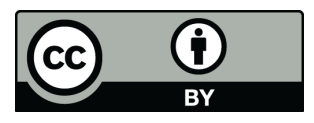

(C) 2018 by the authors. Licensee MDPI, Basel, Switzerland. This article is an open access article distributed under the terms and conditions of the Creative Commons Attribution (CC BY) license (http:/ / creativecommons.org/licenses/by/4.0/). 